\title{
MANAJEMEN USAHA DAN KEMANDIRIAN EKONOMI PESANTREN
}

\author{
Oleh: \\ Djuwairiyah \& Wisri \\ Universitas Ibrahimy Situbondo, Indonesia \\ djuwairiyah.fawaid@gmail.com \\ wisri1976@gmail.com
}

\begin{abstract}
:
The progress of Islamic boarding school education can also be proven by the development of student character. It is not uncommon to find competitions held in Islamic boarding schools, both races among students of Islamic boarding schools, competitions at the village, subdistrict, district, provincial and national levels. The success of the Islamic Boarding School education system is certainly based on reasons. Many factors are the basis of the success of santriwati santriwati in Islamic boarding schools, not only in terms of academics but also in the formation of their character. These factors are also the main attraction of Islamic boarding school.

This study uses qualitative research methods because the intent of the author's research is to know the analysis of Business Management and Economic Independence Nurul Haromain Islamic Boarding School Lembuak Village Narmada District West Lombok Regency. Based on data exposure and discussion of business unit management at Nurul Haramain Islamic Boarding School above, there are a number of points that can be concluded: 1. Nurul Haramain Islamic Boarding School has 14 types of businesses engaged in different fields. The overall management process of the business unit includes business design, Islamic boarding school business dynamics, business benefits and entrepreneurship ethics in Islam. The management model that is applied in the existing business units in Nurul Haromain Islamic Boarding School is the Planning, Organizing, Actuiting and Controlling model which is finally abbreviated to the POAC model. Supporting Factors: Willingness of alumni, guardians of students and sympathizers to help both in energy and mind when needed, the amount of trust and interest of consumers, good enough service and prices are relatively cheap. Inhibiting Factor: The lack of employees who occupy their fields and the existence of several business units in the pesantren complex, as a result the business cannot run properly
\end{abstract}

Keyword: Manajemen Usaha, Kemandirian Ekonomi, Pesantren

$$
\text { JURNAL LISAN AL-HAL } \mid 281
$$




\section{A. Pendahuluan}

Pondok Pesantren merupakan tempat proses belajar agama Islam dan ilmu lainnya dengan model pembelajaran berbentuk asrama dimana para santri(murid) melakukan kegiatan sehari-hari. ${ }^{1}$ Kemajuan pendidikan Pondok Pesantren juga dapat dibuktikan dengan perkembangan karakter siswa. Sudah tidak jarang lagi kita temukan perlombaan-perlombaan yang diadakan di Pesantren baik perlombaan antar santri-santriwati Pesantren, perlombaan tingkat Desa, Kecamatan, Kabupaten, Provinsi hingga tingkat Nasional. Demikian pula jenis mata lomba yang ditawarkan tidak hanya dilingkup keagamaan seperti berpidato, pembacaan kitab kuning, qira'at, dan semacamnya melainkan juga perlombaan di cabang olahraga, pramuka, marching band, dan debat.

Keberhasilan sistem pendidikan Pondok Pesantren ini tentunya berdasarkan pada alasan-alasan. Banyak faktor yang menjadi dasar kesuksesan santri santriwati di Pondok Pesantren, bukan hanya dari segi akademik melainkan juga pembentukan karakter mereka. Faktor-faktor ini juga yang menjadi daya tarik Pondok Pesantren.

Faktor yang dimaksudkan adalah: 1). Pondok Pesantren mengajaran disiplin yang ketat, 2). Pondok Pesantren mengajarkan kemandirian, 3). Pondok Pesantren mengajarkan kreatifitas, 4). Pondok Pesantren mengajarkan keberanian menghadapi banyaknya persoalan hidup, 5). Pondok Pesantren mengajarkan bertanggung jawab ${ }^{2}$.

Fakta tentang kemajuan pendidikan pesantren ini pun menyedot perhatian wali santri baik dengan latar belakang pendidikan yang rendah maupun mereka yang berasal dari keluarga terpandang dan berpendidikan. Tidak sedikit orang tua yang lebih memilih Pesantren sebagai tempat anak mereka menimba ilmu dibandingkan dengan sekolah umum. Hal ini tentunya menjadi kekuatan (strength) yang dapat menghasilkan peluang (opportunity) yang baik bagi perkembangan Pesantren.

Berbanding terbalik dari kenyataan tersebut, image Pondok Pesantren justru umumnya dianggap lemah di bidang ekonomi meski bangunan madrasahnya bertingkat. Anggapan ini kemungkinan muncul dari beberapa fakta seperti rendahnya honor guru, pengajuan bantuan dari madrasah (proposal) baik yang tertuju pada instansi-instansi tertentu

${ }^{1}$ Abdullah Hamid, Pendidikan Karakter Berbasis Pesantren (Surabaya: Imtiyaz, 2017), 48.

2 A. Zainudin, Ketika Sukses Berawal dari Pesantren. (Bekasi: MJWBook PT EMJEWE, 2014), 64.

$282 \mid$ JURNAL LISAN AL-HAL 
maupun pada wali santri, kurangnya sumber daya manusia dalam memanage ekonomi Pondok Pesantren dengan baik.

Kemungkinan lain yaitu kurangnya perhatian pimpinan atau kepala madrasah terhadap perekonomian Pondok Pesantren mengingat tugas serta tanggungjawab pimpinan dan kepala madrasah hanya terkait seputaran pembelajaran dan kegiatan santri. Padahal jika disadari, hubungan antara sistem perekonomian Pondok Pesantren dengan pendidikan Pondok Pesantren merupakan sebuah simbiosis mutualisme dimana dunia usaha mampu memberi dukungan dan memperkuat kehidupan (pendidikan) Pondok Pesantren. Sebaliknya Pondok Pesantren dapat menjadi pendukung moral bagi terselenggaranya dunia usaha dan industri secara baik. ${ }^{3}$

Dr. Muhammad Syafii Antonio dalam bukunya yang berjudul 'Muhammad SAW The Super Leader, Super Manager' menyatakan bahwa sebagian besar kehidupan nabi Muhammad sebelum menjadi rasul digunakan untuk berdagang (enterpreneurship) sehingga beliau pun ahli dalam berbisnis. ${ }^{4}$ Sejarah juga mencatat bahwa tidak sedikit dari nabinabi terdahulu yang berprofesi sebagai pengusaha. Nabi Zakaria menjadi tukang kayu, Nabi Idris menjahit pakaian, dan Nabi Daud membuat baju perang. Tentunya ini menjadi salah satu dalil akurat pentingnya berniaga, bahkan Rasulullah pernah menyebutkan bahwa seseorang yang bekerja dengan tangan sendiri dan jual beli yang bersih merupakan pekerjaan yang paling mulia. ${ }^{5}$

Kepemimpinan yang baik dalam suatu Pondok Pesantren tentunya akan memberikan manfaat maksimal bila digabungkan dengan manajemen ekonomi yang baik pula. Bukan hanya untuk kemandirian Pesantren, manajemen ekonomi yang baik juga memiliki andil yang sangat urgent untuk kemajuan pendidikan Pesantren. Bagaimana tidak, ketika ekonomi Pesantren bagus maka Pesantren bisa memberi dukungan dana terhadap santri-santriwati mereka untuk melakukan kegiatan-kegiatan (program kerja) yang edukatif yang kemudian secara perlahan mempengaruhi dan membentuk kreatifitas serta keperibadian peserta didik. Hal ini tidak bisa dipungkiri mengingat dana bisa menjadi salah satu kendala terbentuknya suatu program, sedangkan ketiadaan atau

3 Sulthon \& Khusnuridlo, Manajemen Pondok Pesantren dalam Perspektif Global. (Yogyakarta: LaksBang PRESSindo, 2006), 257.

4 Muhammad Syafii Antonio, Muhammad SAW The Super Leader, Super Manager, Netlibrary E-Book.

5 A. Tanjung, Budaya Bisnis Menuju Kebangkitan Ekonomi Syariat (Jakarta: Dewan Pimpinan Majelis Ulama Indonesia (MUI) Pusat, 2012), 90. 
kurangnya program dalam suatu pesantren bisa menimbulkan kebosanan bahkan pembunuhan karakter peserta didik.

Selain itu, pengadaan dan pengelolaan unit usaha memungkinkan kemandirian ekonomi suatu lembaga pendidikan yang memang sudah menjadi keharusan untuk membentuk perubahan positif. Bagaimana tidak, sekolah non swasta (sekolah negeri) khususnya mendapat bantuan dana penuh dari Pemerintah baik untuk honor guru, kebutuhan belajarmengajar serta pengadaan sarana dan prasarana sekolah. Sedangkan sekolah swasta hanya mendapatkan bantuan yang nominalnya tergantung pada jumlah santri sehingga pengurus pesantren harus aktif dan kreatif mengelola perekonomiannya sendiri.

Tetapi bagaimanapun mengelola perekonomian sendiri bukanlah pertanda ketertinggalan suatu lembaga pendidikan. Justru hal ini mampu menjadi ciri khas dan loncatan menuju kemandirian ekonomi dan sosial Pondok Pesantren yang mana dengan kemandirian tersebut, sebuah lembaga pendidikan akan mampu bertindak bebas mengelola sistem pendidikan sebagaimana yang diinginkan. Kemungkinan ini didukung oleh potensi ekonomi Pondok Pesantren yang sangat tinggi dengan adanya tiga unsur dalam Pondok Pesantren, yaitu kiai, santri dan sistem pendidikan. ${ }^{6}$

Semakin banyak santri/santriwati yang terdaftar maka semakin besar pula potensi ekonomi Pondok Pesantren, apalagi dikaitkan dengan kebutuhan mereka yang beragam. Bagaimana tidak, suatu Pesantren dengan jumlah santri yang banyak akan menerima uang pendaftaran dan iuran yang lebih banyak pula. Dana ini kemudian dapat dimanfaatkan sebagai modal usaha Pondok Pesantren. Fakta lain, ketika Pondok Pesantren memiliki santri yang banyak maka pengajar yang dibutuhkan dan wali santri yang datang berkunjung pun bertambah, ini berarti populasi Pondok Pesantren meningkat. Populasi inilah yang nantinya akan menjadi konsumen sehingga potensi ekonomi Pondok Pesantren terjamin.

Pengelolaan ekonomi secara mandiri juga menentukan kemajuan suatu lembaga pendidikan. Salah satu syarat, bahkan ciri suatu lembaga pendidikan itu berkualitas dinilai dari ketersediaan sarana prasarana yang cukup untuk menunjang terpenuhinya kebutuhan belajar serta penyaluran bakat dan minat siswa dalam kegiatan ekstrakurikuler. ${ }^{7}$ Pastinya dibutuhkan dana yang tidak sedikit untuk mewujudkan hal tersebut, sehingga usaha mandiri adalah salah satu solusinya. Jika hanya

${ }^{6}$ A. Halim, et al., Manajemen Pesantren (Yogyakarta: Pustaka Pesantren), 222.

7Anwar, "Sekolah madrasah berkualitas", dalam http://portalgaruda.org/article.php (05 februari 2019), 13.

$284 \mid$ JURNAL LISAN AL-HAL 
mengandalakan sumbangan pemerintah, maka pendidikan yang diperoleh siswa akan kurang maksimal.

Salah satu lembaga pendidikan Islam yang menjalankan program manajemen ekonomi secara mandiri adalah Pondok Pesantren Nurul Haromain yang terletak di Desa Lembuak Kebon Kecamatan Narmada Lombok Barat. Pengelolaan unit usaha di Pondok Pesantren Nurul Haromain dimulai dari awal berdirinya pada tahun 1992. Unit usaha pertama yang terbentuk waktu itu adalah kantin sekolah, dan seiring bertambahnya jumlah dan kebutuhan santri tumbuh lah berbagai macam unit usaha baru yang bergerak dibidang yang berbeda seperti mini market, laundry, travel. Saat ini Pondok Pesantren sudah memiliki empat belas jenis unit usaha tetap. ${ }^{8}$

Berdasarkan paparan di atas, penelitian ini menekankan pada :

1. Bagaimana proses manajemen usaha pada kemandirian ekonomi di Pondok Pesantren Nurul Haromain Desa Lembuak Kecamatan Narmada Kabupaten Lombok Barat?

2. Apa saja faktor pendukung dan penghambat proses manajemen usaha pada kemandirian ekonomi di Pondok Pesantren Nurul Haromain Desa Lembuak Kecamatan Narmada Kabupaten Lombok Barat?

Keberadaan unit usaha inipun sangat berpengaruh terhadap kehidupan para pengelola yang tiada lain adalah guru-guru di Pesantren sendiri. Selain mendapatkan tambahan income setiap bulannya, hal yang jauh lebih penting yang diperoleh pengelola yaitu kemampuan berwirausaha. Ini memang merupakan tujuan utama mengapa unit usaha dikelola langsung oleh para guru. Mereka diharapkan mampu menimba ilmu enterpreneurship di Pesantren untuk kemudian dikembangkan di masyarakat luas nantinya sehingga paling tidak mereka mampu mandiri tanpa harus membebani keluarga atau orang lain. Selebihnya mereka juga diharapkan mampu menularkan ilmu wirausaha yang dimiliki pada keluarga dan masyarakat terdekat.

Melihat hasil yang sudah ada, manajemen ekonomi Pesantren Nurul Haromain sudah mampu mencapai tujuan-tujuannya. Fakta ini menjadi salah satu alasan menarik kenapa penelitian ini mengangkat tema kewirausahaan lembaga pendidikan yang ada di Pondok Pesantren Nurul Haromain. Disamping memperhatikan pengaruh positifnya terhadap suasana dan kondisi lingkungan yang tercipta, alasan lainnya adalah inisiatif peneliti menghasilkan sebuah karya tulis terkait pengaruh wirausaha terhadap berbagai aspek dalam sebuah lembaga pendidikan,

8 Anwar Thayyib, Wawancara, Narmada, 01 Juni 2019.

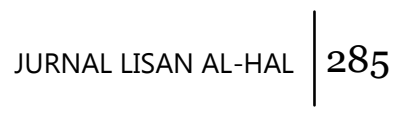


terutama Pondok Pesantren sehingga dapat dijadikan referensi dalam pengelolaan suatu manajemen pendidikan berbasis wirausaha. ${ }^{9}$

\section{B. Manajemen dalam Dunia Usaha}

Istilah manajemen berasal dari kata kerja to manage yang berarti kontrol. Dalam bahasa Indonesia bisa diartikan mengendalikan, menangani atau mengelola. Selanjutnya, 'manajemen' atau management merupakan bentuk kata benda yang memiliki berbagai arti. Stoner dkk., pada buku yang ditulis oleh Wijayanto mengemukakan bahwa manajemen adalah proses perencanaan, pengorganisasian, pengarahan dan pengawasan terhadap usaha-usaha para anggota organisasi dan penggunaan sumber-sumber daya organisasi lainnya agar mencapai tujuan organisasi yang telah ditetapkan."10

George dalam Herujito mencoba memberikan definisi manajemen yang lebih luas. Ia menyatakan bahwa manajemen adalah suatu proses yang berbeda terdiri dari planning, organizing, actuating dan controlling yang dilakukan untuk mencapai tujuan yang ditentukan dengan menggunakan manusia dan sumber daya lainnya. Pengertian ini bisa dimaknai bahwa manajemen terbentuk dari setiap kegiatan yang berbeda karena mereka (manajemen dan kegiatan yang berbeda-beda) merupakan proses yang tidak dapat dipisahkan dan sangat erat hubungannya. ${ }^{11}$

Naja Hasanuddin Rahmman Daeng dalam buku Manajemen Fit and Profer test nya menguraikan kelima elemen tersebut. Men berarti orangorang yang terlibat (SDM) atau yang lebih dikenal sebagai stakeholder, melakukan aktifitas dan yang menggerakkan orang lain lagi. Materials adalah bahan atau informasi manajemen yang tersedia baik yang berupa feedback ataupun akibat dari aktifitas organisasi perusahaan yang dibutuhkan oleh stakeholder. Machine adalah peralatan baik yang digunakan perusahaan maupun stakeholder. Methods adalah cara kerja atau sistem dan prosedur yang ditetapkan untuk setiap unit atau subsistem dalamorganisasi perusahaan. Sedangkan money adalah modal organisasi perusahaan dalam menjalankan aktifitasnya. ${ }^{12}$

${ }^{9}$ Observasi , 09 Januari 2019.

10 Dian Wijayanto, Pengantar Manajemen (Jakarta: PT Gramedia Pustaka Utama, 2012), 1.

11 Ibid, 2.

12 Naja Hasanuddin Rahman Daeng, Manajemen Fit and Profer Test (Yogyakarta: Pustaka Widyatama, 2004), 3.

286 JURNAL LISAN AL-HAL 
Berikut penjelasan masing-masing istilah:

a) Proses (processing) adalah cara yang sistematis untuk melakukan sesuatu. Setiap orang yang terlibat dalam suatu manajemen, apapun keahlian dan keterampilan yang mereka miliki, mereka akan terlibat dan harus bekerjasama dalam kegiatan-kegiatan yang saling berkaitan untuk mencapai tujuan organisasi.

b) Perencanaan (planning), manajer harus terlebih dahulu memikirkan bagaimana menjalankan manajemen (kegiatan) dan tujuan manajemen yang dibentuk.

c) Pengorganisasian (organizing), berarti manajer mengkoordinasikan sumberdaya yang dimiliki perusahaan, semakin baik koordinasi yang dilakukan, maka akan semakin baik hasil yang didapatkan.

d) Penggerakan (actuating), menunjukkan cara bagaimana manajer mengawasi, mengarahkan dan mempengaruhi bawahannya, menggunakan orang lain untuk menjalankan tugas tertentu.

e) Pengendalian (controlling), berarti manajer berusaha sebaik mungkin agar manajemen yang dibentuk bergerak ke arah tujuan, bukan malah bergerak ke belakang menjauhi tujuan. Jika ada bagian organisasi yang bergerak ke arah yang berbeda dari tujuan, manajer harus mencari tahu penyebabnya kemudian bergerak mengarahkan bagian tersebut menuju ke arah tujuan. ${ }^{13}$

\section{Proses dan Fungsi Manajemen}

Usaha yang sukses merupakan buah produk atau layanan yang baik yang dihasilkan melalui proses pengelolaan (manajemen) yang baik. Produk dan layanan yang baik tidak akan pernah tercipta sebelum proses yang baik dijalankan karena proses merupakan sebab (input) sedangkan produk dan layanan byang baikadalah akibat atau hasil (ouput) dari proses tersebut. Proses yang baik juga mempengaruhi keeksisan dan tingkat kepercayaan konsumen,bahkan dapat menentukan jenis konsumen seperti apa yang diinginkan. Oleh karena itu, dengan berbagai macam alasan positif, proses yang baik merupakan tindakan yang sangat penting.

Selain sebagai aktivitas mentransformasikan input menjadi output, Michael Hammer dalam Purnawanto menyebutkan bahwa proses merupakan kumpulan task yang dikerjakan secara bersama untuk menghasilkan value bagi bagi customer. ${ }^{14}$ Task merupakan sebuah unit

13 Ibid, 21.

${ }^{14}$ Budy Purnawanto, Manajemen SDM Berbasis Proses,(Yogyakarta: Pustaka Widyatama, 2004), 46. 
kerja atau aktivitas kerja yang dilakukan pengelola secara bersama yang kemudian dapat menghasilkan suatu produk yang bernilai (value) bagi para konsumen.

Menurut Abdullah Halim secara umum proses manajemen dapat dikelompokkan menjadi:

\section{Goal setting}

Goal setting atau penetapan tujuan merupakan langkah paling awal dalam suatu manajemen. Tujuan suatu manajemen semestinya baik dan bermanfaat. Kriteria tersebut bisa dinilai melalui: a). Spesifik; apa yang ingin dicapai harus jelas, b). Realistis; tujuannya memungkinkan untuk dicapai, tidak berlebihan. c). Terukur; memiliki ukuran yang jelas dalam menentukan keberhasilan. d). Terbatas waktu; memiliki batasan waktu sebagai target atau deadline tujuannya tercapai.

\section{Planning}

Planning atau perencanaan merupakan proses pemilihan informasi dan pembuatan asumsi mengenai keadaan dimasa yang akan datang untuk merumuskan kegiatan-kegiatan yang perlu dilakukan dalam rangka pencapaian tujuan yang telah ditetapkan sebelumnya. Planning ini dapat berupa kebijaksaan (policy) mengenai batasan kegiatan secara umum dan komprehensif, prosedur (procedure) mengenai tata cara pengerjaan kegiatan secara kronologis, metode (method) mengenai tindakan yang harus dilakukan, standar (standard) mengenai gambaran pencapaian yang diharapkan, anggaran (budgetting) mengenai penerimaan dan pengeluaraan keuangaan, serta program (programme) menyangkut pemakaian sumberdaya secara integratif, termasuk didalamnya jadwal pelaksanaan kegiatan.

\section{Staffing}

Staffing adalah proses manajemen yang berkenaan dengan pengerahan (recruitment), penempatan, pelatihan dan pengembangan tenaga kerja dalam organisasi. Prinsip dasarnya adalah menempatkan orang yang tepat (right people) pada tempat atau posisi yang tepat (right position) dan di waktu yang tepat (right time).

4. Directing

Directing adalah usaha untuk memobolisasi sumber-sumber daya yang dimiliki oleh organisasi agar dapat bergerak dalam satu kesatuan sesuai dengan rencana yang telah ditentukan.

\section{Supervising}

Supervising adalah interaksi langsung antara individu dalam suatu organisasi untuk mencapai kinerja yang optimal. 


\section{Controlling}

Pengendalian adalah proses penetapan apa yang telah dicapai, dengan kata lain dikenal dengan evaluasi kinerja, serta pengadaan perbaikan jika kinerja yang dihasilkan belum sesuai dengan tujuan yang ditentukan di awal. ${ }^{15}$

Berdasarkan proses-proses manajemen yang telah diuraikan di atas, Griffin mendeskripsikan 4 jenis fungsi manajemen yaitu sebagai penentuan perencaan atau pengambilan keputusan, pengorganisasian, pengendalian dan kepemimpinan. ${ }^{16}$ Proses manajemen digerakkan oleh seorang pemimpin yang disebut manager. Untuk menjalankan manajemen dengan baik, manager tentunya membutuhkan keahlian khusus, bukan saja keahlian teknis melainkan juga kemampuan memimpin yang baik. Ia memegang kendali penuh atas pekerjaan orang-orang yang terlibat.

Menurut Schermerhorn dalam Wijayanto, ada tiga jenis keterampilan yang dibutuhkan seorang manajer dalam menjalankan sebuah manajemen. Tiga keterampilan tersebut adalah:

1. Kemampuan teknis (technical skill); kemampuan untuk mengaplikasikan pengetahuan dan pengalaman yang bersifat teknis dan spesialis.

2. Kemampuan antarpribadi (human skill); kemampuan untuk saling memahami, bekerja sama, memahami dan memotivasi orang lain, baik secara individumaupun kelompok.

3. Kemampuan konseptual (conceptual skill); kemampuan untuk menganalisis dan mendiagnosis permasalahan yang kompleks yang meliputi proses identifikasi masalah, mengembangkan alternatif solusi, mengevaluasi dan memilih solusi yang terbaik. ${ }^{17}$

Pada intinya, ketiga kemampuan diatas sangat dibutuhkan seorang manajer. Tetapi semakin tinggi level seorang manajer maka conceptual skill lah yang paling dibutuhkan karena dia harus mampu menguasai strategi bagaimana agar usahanya mampu bersaing di tingkat yang lebih tinggi.

\section{Dinamika Usaha Pondok Pesantren}

Berdasar pada hitungan matematis-ekonomis, lingkungan pesantren terkenal sebagai lingkungan miskin dikarenakan letaknya yang

15 Ibid, 23.

16 RickyW. Griffin, Manajemen (Jakarta: Erlangga, 2004), 9.

17 Dian Wijayanto, 2012. Pengantar Manajemen (Jakarta: PT Gramedia Pustaka Utama), 4. 
selalu berada disekitaran pedesaan. Pedesaan dikenal sebagai lingkungan yang memiliki perkembangan lamban dari segi ekonomi sehingga mempengaruhi kehidupan lingkungan pesantren. ${ }^{18}$ Pondok Pesantren memiliki sistem pendidikan kultur yang unik yang mana dengan keunikannya tersebut Pondok Pesantren digolongkan ke dalam subkultur tersendiri di masyarakat Indonesia. ${ }^{19}$

Setidaknya ada tiga unsur yang meyakinkan Halim terkait potensi ekonomi pesantren yang menjanjikan. Pertama, sosok kepemimpinan seorang kiai (ulama). Bagaimana keunikan kepemimpinan kiai-ulama dalam sebuah pesantren dilihat sebagai potensi ponpes yang bernilai ekonomis? Jawaban pertanyaan ini tidak terlepas dari tiga kenyataan, yaitu figur kiai-ulama yang cukup menjual dikarenakan kedalaman ilmunya. Tingkat penguasaan ilmu agama yang tinggi inilah yang menjadi magnet luar biasa bagi masyarakat untuk menimba ilmu di pesantren. Kiai-ulama merupakan panutan masyarakat yang memunculkan kepercayaan masyarakat yang besar, dari kepercayaan ini lahirlah akses. Dan kemandirian ekonomi kiai-ulama sebelum mendirikan pesantren, seperti menjadi seorang petani dan pengusaha (enterpreneur).

Kedua, potensi ekonomi yang menjanjikan dalam Pondok Pesantren adalah santri atau murid. Tidak dipungkiri bahwa setiap individu memiliki potensi berbeda, begitupun dengan santri. Ketiga adalah unsur pendidikan. Sistem pendidikan pesantren, seperti yang telah dibahas sebelumnya, merupakan model pendidikan yang unik dimana terdapat paduan antara sistem pengajaran nonklasikal dengan modern yang klasikal. Selain itu, pendidikan pesantren juga unggul dari segi kegiatan dan disiplin ilmu.

Dalam sebuah lembaga pendidikan, lazimnya akan terdapat siswasiswi, guru, serta sarana-prasarana. Begitupun di pesantren. Dari para santri nantinya pesantren akan mendapatkan iuran, baik itu iuran asrama, listrik, air, makan, dan sebagainya. Selain itu, para santri ini tentunya membutuhkan sarana belajar seperti buku, alat tulis, dan seragam sekolah agar dapat mengikuti proses pembelajaran dengan baik. Dengan memperhatikan hal ini, Pondok Pesantren seharusnya memiliki unit usaha yang menyediakan kebutuhan santri-santriwati mereka. Iuran

18 Rofiq A. et al., Pemberdayaan Pesantren Menuju Kemandirian dan Profesionalisme Santri dengan Metode Daurah Kebudayaan (Yogyakarta: Pustaka Pesantren, 2005), 15.

19 Abdullah Halim et al., Manajemen Pesantren (Yogyakarta: Pustaka Pesantren), 222.

$290 \mid$ JURNAL LISAN AL-HAL 
pembayaran santri bisa dimanfaatkan sebagai modal awal terbentunya unit usaha yang dimaksudkan.

\section{E. Etika Berwirausaha dalam Islam}

Sebagian orang merasa memiliki usaha sendiri pastinya lebih memuaskan walaupun dengan penghasilan secukupnya daripada mendapatkan penghasilan besar tetapi harus bekerja untuk orang lain.

Sekitar $86 \%$ orang memilih bekerja sendiri, sedangkan sisanya memilih bekerja untuk orang lain. ${ }^{20}$ Hal ini kemungkinan disebabkan karena mereka mampu merasakan manfaat dari wirausaha yang dijalankan. Menurut Zimmerer setidaknya ada beberapa manfaat dari wirausaha: 1). Peluang untuk melakukan perubahan, 2). Peluang untuk mencapai potensi sepenuhnya, 3). Peluang untu meraih keuntungan yang menakjubkan, 4). Peluang untuk berperan dalam masyarakat dan mendapatkan pengakuan atas usaha anda dan 5). Peluang untuk melakukan sesuatu yang anda sukai. ${ }^{21}$

Islam memandang kehidupan manusia sebagai kehidupan yang berkelanjutan. Dalam pandangan Islam, kehidupan manusia dimulai sejak kelahirannya namun tidak terhenti pada saat kematiannya. Dengan adanya keyakinan tersebut, Islam tidak hanya menganjurkan manusia untuk meraih sukses di dunia melainkan juga kesuksesan di akhirat. Setiap perbuatan seseorang di dunia akan mempengaruhi kehidupan manusia di akhirat setelahnya, baik yang positif atau perbuatan baik, dan juga negatif atau perbuatan jelek.

Berkaitan dengan hal tersebut, konsep Islam (Al Quran) tentang wirausaha (enterpreneurship) yang sebenarnya serta yang disebut beruntung dan rugi hendaknya dilihat dari seluruh perjalanan hidup manusia. $^{22}$ Untuk mencapai keberuntungan yang sejati, seorang pengusaha tidak boleh mengenyampingkan aturan-aturan syar'i yang telah ditetapkan agama Islam berkaitan dengan dunia bisnis.

Adapun syari'at-syari'at Islam tentang kewirausahaan telah banyak disebutkan di dalam Al Quran seperti beberapa contoh berikut:

20 Thomas W. Zimmerer et al., Essentials of Enterpreneurship and Small BusinesManagement. Kewirausahaan dan Manajemen Usaha Kecil (Jakarta: Salemba Empat, 2008), 10.

21 Ibid, 11.

22 Mushtaq Ahmad, Etikabisnis dalam Islam (Jakarta Timur: Pustaka Al-Kautsar, 2001), 36. 
a. Al Baqarah:275- 276

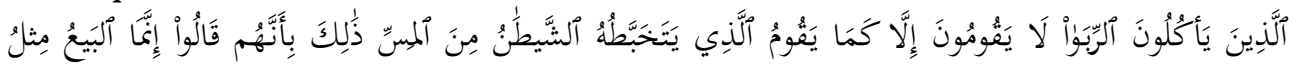

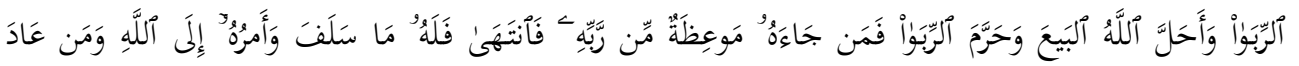

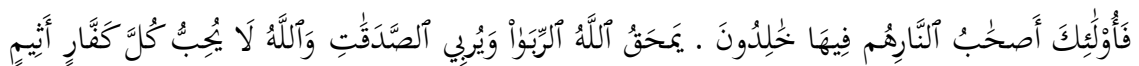

"Orang-orang yang makan riba tidak berdiri melainkan seperti berdirinya orang kemasukan setan karena gila. Yang demikian itu karena mereka berkata bahwa jual beli itu sama dengan riba padahalAllah telah menghalalkan jual beli dan mengharamkan riba. Barangsiapa mendapat peringatan dari tuhannya dan berhenti, maka apa yang telah diperolehnya dahulu menjadi miliknya dan urusannya terserah kepada Allah. Barangsiapa mengulangi, maka mereka itu penghuni neraka, mereka kekal di dalamnya. (275) Allah memusnahkan riba dan menyuburkan sedekah. Allah tidak menyukai setiap orang yang tetap dalam kekafiran dan selalu berbuat dosa. (276)"23

b. Al Mujadilah: 6

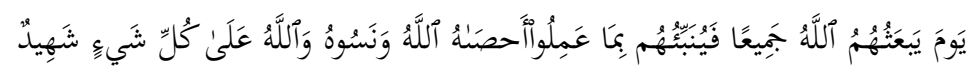

"Pada hari ketika mereka dibangkitkan Allah semuanya, lalu diberikannyakepada mereka apa yang telah mereka kerjakan. Allah mengumpulkan (mencatat) amal perbuatan itu padahal mereka sendiri telah melupakannya. Dan Allah Maha Menyaksikan segala sesuatu."24

Masih banyak sekali ayat Al Quran yang menjelaskan tentang cara berwirausaha yang benar dan dapat memberikan keberkahan (keberuntungan) untuk hidup manusia di dunia dan di akhirat. Secara keseluruhan dapat disimpulkan bahwa untuk menjalankan usaha yang menguntungkan (berkah), harus ada tiga elemen dasar pada setiap usaha yaitu:

Pertama, Investasi modal yang sebaik-baiknya. Dalam Islam ada sepotong hadits yang dihafal oleh hampir seluruh muslim. Hadits tersebut berbunyi:

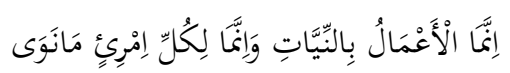

"Sesungguhnya setiap perbuatan itu dinilai menurut niatnya"25 h. 47 .

${ }^{23}$ Kementrian Agama RI, Al-Quran dan Terjemah, (Bandung: CV Diponogoro, 2010)

24 Ibid,542.

25 Muhammad bin Isma'il, Sarah Shohih Bukhari, (Damaskus: Dar Al-Bayan, 1990), Juz. 5, h. 3 .

292 JURNAL LISAN AL-HAL 


\section{investasi.}

Hadits di atas bisa dijadikan rujukan mengenai sebaik-baik

Kedua, Membuat keputusan yang sehat dan logis. Agar sebuah bisnis sukses dan menguntungkan, hendaknya bisnis didasarkan pada keputusan yang sehat dan logis dengan mengutamakan apa yang disebut dengan thayyib (baik) dan halal, serta menghindari yang syak (meragukan), khabits (jelek) dan yang haram dari segi produk dan cara pengelolaan bisa dijadikan salah satu cara terbaik untuk pengambilan keputusan yang sehat dan logis dalam suatu usaha.

Ketiga, Mengikuti perilaku yang baik. Panduan dan tolak ukur perilaku seseorang yang baik telah dipaparkan dalam al Quran. Sebagiannya sudah dituliskan di awal pembahasan sub ini. Intinya al Quran senantiasa menyuruh kaum muslimin wal muslimat untuk mengikuti setiap jejak dan sifat Rasulullah SAW seperti shiddiq (jujur) amanah (terpercaya) ikhlash (tulus), asshobru (penyabar), tawadhu' (rendah hati), istiqamah (konsisten), dsb. Denganmemiliki sifat-sifat terpuji tersebut seseorang akan memiliki pegangan yang baik dan kokoh dalam mengelola usaha. ${ }^{26}$

Selain tiga hal penting di atas, ada hal lain juga yang harus diketahui terkait etika bermu'amalat yaitu jenis usaha yang sah tetapi terlarang menurut Islam. Sah karena memenuhi rukun jual beli, tetapi terlarang karena dikhawatirkan berpotensi menyakiti salah satu pihak, baik penjual atau pun pembeli, menyempitkan gerakan pasaran, dan merusak ketentraman umum. ${ }^{27}$

Adapun jual beli yang dimaksud adalah:

1) Membeli barang dengan harga yang lebih mahal dari harga pasar dengan niat agar orang lain tidak dapat membeli barang tersebut, sedangkan dia tidak butuh terhadap barang tersebut.

2) Membeli barang yang sudah dibeli orang lain yang masih dalam masa khiyar.

3) Menghambat pedagang menuju pasar dan membeli barangnya ditengah jalan, sedangkan pedagang tersebut belum tahu harga pasar.

4) Menimbun barang untuk dijual dengan harga yang lebih mahal.

5) Barang yang diperjualbelikan dipergunakan untuk melakukan kemaksiatan.

${ }^{26}$ Nashruddin Baidan and Erwati Aziz, Etika Islam dalam Berbisnis (Jawa Tengah: Zada Haniva, 2008), 96.

27 Saifullah Ma'shum, Fiqih Islam Lengkap. Pedoman Hukum Ibadah Umat Islam dengan Berbagai Permasalahannya (Surabaya: Terbit Terang, 2000), 122. 
6) Jual beli yang mengandung unsur tipuan.

Yang lebih penting lagi yaitu jenis mu'amalat yang diharamkan dalam Islam, hukum jual belinya tidak sah dan terlarang. Jenis-jenis tersebut adalah:

1) Menjual air mani binatang sebagai bibit ternak;

2) Menjual anak ternak yang masih dalam kandungan;

3) Menjualbelikan barang yang baru dibeli sebelum diterimakan kepada pembelinya;

4) Menjual hasil tanaman sebelum nyata hasilnya. ${ }^{28}$

\section{F. Kemandirian Ekonomi}

Kemandirian berasal dari kata 'diri' yang berarti tidak terlepas dari perkembangan diri seorang individu. Diri merupakan inti keperibadian. Secara umum dapat dikatakan bahwa kemandirian adalah kemampuan dan kesiapan seseorang untuk berdiri sendiri dalam pengambilan keputusan, penyelesaian masalah dan memiliki upaya untuk terus melangkah menuju perkembangan. ${ }^{29}$

Kemandirian tumbuh dan berkembang karena dua faktor, yaitu disiplin dan komitmen terhadap kelompok. Oleh karena itu, seseorang yang mandiri dapat dikenali melalui keberaniannya mengambil keputusan sendiri berdasarkan pengetahuan dan pemahamannya akan segala konsekuensi yang akan terjadi atas tindakannya. ${ }^{30}$ Kemandirian jenis ini merupakan contoh dari kemandirian sosial dimana satu individu tidak membebani individu lainnya dengan masalah-masalahnya. Sedangkan bentuk kemandirian lainnya adalah kemandirian ekonomi yang ditandai dengan kemampuan satu individu mencukupi kebutuhannya sendiri dengan pendapatan yang cukup.

Untuk mengetahui apakah satu individu, dalam hal ini lembaga pendidikan yaitu Pondok Pesantren, sudah mandiri atau belum dapat disimpulkan dari definisi berikut. Kemandirian adalah suatu sikap yang memungkinkan seseorang untuk bertindak bebas melakukan sesuatu atas dorongan sendiri dan untuk kebutuhannya sendiri tanpa bantuan orang lain, berfikir dan bertindak original/kreatif, dan penuh inisiatif, mampu mempengaruhi lingkungan, mempunyai rasa percaya diri, serta

28 Ibid, 123.

${ }^{29}$ Lenny Oktavia et al., Pendidikan Karakter Berbasis Tradisi Pesantren (Jakarta: Tim Penulis Rumah Kitab, 2014), 211.

30 Ibid, 211.

$294 \mid$ JURNAL LISAN AL-HAL 
memperoleh kepuasan dari hasil usahanya. ${ }^{31}$ Jadi, mandiri berarti: 1).Mampu bertindak bebas 2). Melakukan sesuatu untuk kebutuhan sendiri karena inisiatif sendiri, 3). Tidak mengharapkan bantuan yang lain, 4). Berfikir dan bertindak original dan kreatif, serta penuh inisiatif, 5). Fikiran dan tindakannya mampu memberikan dampak terhadap yang lain, 6). Memiliki rasa percaya diri yang tinggi dan 6). Hasil yang diperoleh memuaskan.

Terkait hal tersebut, kemandirian baik dari segi sosial maupun ekonomi dapat dijadikan salah satu ciri berkembangnya lembaga pendidikan, khususnya Pondok Pesantren. Kemandirian ini sangat menentukan perjalanan Pondok Pesantren, apalagi menyadari kenyataan bahwa Pondok Pesantren sebagai lembaga pendidikan swasta berada di luar tanggungan pemerintah. Kurangnya kemandirian memungkinkan turunnya nilai Pondok Pesantren baik dari segi kualitas maupun kuantitas.

Dalam penelitian ini peneliti ingin mengetahui manajemen usaha di Pondok Pesantren Nurul Haromain Desa Narmada Kab. Lombok Barat serta apa saja faktor pendukung dan penghambatnya. Untuk mengetahui manajemen usaha, peneliti menggunakan konsep manajemen usaha.

Manajemen usaha yang digunakan oleh unit-unit usaha yang ada di Pondok Pesantren Nurul Haromain tersebut akan di analisa oleh peneliti dan dijadikan landasan penelitian, yang artinya hasil penelitian dilapangan akan di padukan dengan teori yang ada, sehingga bisa terlihat apakah manajemen usaha yang digunakan tersebut mampu memandirikan Pesantren atau tidak.

\section{G. Metode Penelitian}

Penelitian ini menggunakan metode penelitian kualitatif dikarenakan maksud dari penelitian penulis adalah untuk mengetahui analisis Manajemen Usaha dan Kemandirian Ekonomi Pondok Pesantren Nurul Haromain Desa Lembuak Kecamatan Narmada Kabupaten Lombok Barat, data yang dibutuhkan oleh peneliti dikelompokan menjadi dua jenis data, yaitu data primer 32 dan data sekunder ${ }^{33}$. Sumber data menurut Lofland yang diterjemahkan oleh Lexy J. Moleong berarti kata-kata dan tindakan, selebihnya adalah data tambahan seperti dokumen dan lainlain. ${ }^{34}$

31 Ibid, 233.

32 Sedarmayanti, et al., Metodologi Penelitian, 73.

33 Muhammad, Metodelogi Penelitian Ekonomi Islam, (Jakarta: Rajawali Pers, 2008), 73.

34Lexy, 157. 
Teknik pengumpulan data merupakan langkah yang paling strategis dalam penulisan karena tujuan utama dari penulisan adalah mendapatkan data. Tanpa mengetahui teknik pengumpulan data, maka peneliti tidak akan mendapatkan data yang memenuhi standart data yang ditetapkan. Secara umum terdapat tiga macam teknik pengumpulan data, yaitu: Observasi, Interview/ Wawancara dan Dokumentasi. . ${ }^{35}$

Menurut Winarno Surakhmad penelitian deskriptif adalah penelitian yang tertuju pada pemecahan masalah pada masa sekarang. Pelaksanaan metode deskriptif tidak hanya terbatas pada pengumpulan data dan penyusunan data, tapi meliputi analisa dan interpretasi tentang arti data itu. ${ }^{36}$

Metode analisis yang dilakukan dalam penelitian ani adalah teknik analisis data induktif. Metode induktif adalah teknik atau metode yang berangkat dari pengetahuan yang bersifat umum dan khusus menjadi umum. Induksi adalah kerja ilmu pengetahuan yang bertolak dari sejumlah propoisi tunggal atau partikular tertentu lalu ditarik kesimpulan yang dianggap benar dan berlaku umum. Dalam hal ini kebenaran kesimpulan adalah bersifat sementara dan dan tidak mutlak. Analisis data induktif menurut paradigma naturalistik adalah analisis atas data spesifik dari lapangan menjadi unit-unit dilanjutkan dengan kategorisasi. Artinya kesimpulan umum didapatkan setelah mendapatkan temuan-temuan atas analisa Manajemen Usaha dan Keandirian Ekonomi Pondok Pesantren yang ada di Desa Lembuak, Narmada. ${ }^{37}$

Analisis data merupakan salah satu proses untuk mencari data dan menyusun secara sistematis yang didapat dari hasil wawancara, catatan lapangan dan dokumentasi, dengan tujuan untuk memahami sebuah fakta dan makna dari data yang telah di analisis. Setelah data yang diperlukan dalam penelitian ini terkumpul, maka langkah selanjutnya adalah mengolah data dengan suatu metode tertentu agar lebih proporsional dan representatif. Adapun metode analisis yang digunakan dalam penelitian ini adalah teknik analisis reduksi data, display data (penyajian data), dan konklusi/ Coclusion (kesimpulan). . ${ }^{38}$

Keabsahan data merupakan konsep penting yang diperbaharui dari

\footnotetext{
${ }^{35}$ Sustrisno Hadi, Metodologi Research (Yogyakarta: Andi Offset, 1981), 136.

${ }^{36}$ Winarno Surahmad, Pengantar Penelitian Ilmiah dan Metode Tehnik, (Bandung: Alfabeta, 1990), 139.

37 Noeng Muhadjir, Metodologi Penelitian Kualitatif, (Yogyakarta: PT Bayu Indah Grafik, 1996), 109.

${ }^{38}$ Sugiono, Metode Penelitian Kuantitatif, Kualitatif dan R\&D, (Bandung: PT Remaja, 2012), 247.

296 JURNAL LISAN AL-HAL
} 
konsep kesahihan (validitas) dan keterandalan (reliabilitas). Peneliti merupakan kerja ilmiah, untuk melakukan ini mutlak di tuntut secara objektivitas, untuk memenuhi kriteria ini dalampenelitian maka kesahihan (validitas) dan keterandalan (reliabilitas) harus dipenuhi, kalau tidak maka proses penelitian itu perlu di pertanyakan keilmiahannya. ${ }^{39}$

\section{H. Perencanaan (Planning) Usaha Pondok Pesantren Nurul Haramain}

Dari sejak berdirinya tahun 1992 sampai saat ini, pondok pesantren Nurul Haramain sudah mampu menjalankan 14 jenis unit usaha yang bergerak dibidang yang berbeda. Keseluruhan usaha tersebut dikelola langsung oleh para alumni dibawah arahan dan bimbingan Ahmad Dahlan selaku kordinator usaha sekaligus kepala sekolah Madrasah Aliyah Nurul Haramain. Adapun unit usaha pondok pesantren Nurul Haramain yang dimaksudkan adalah Haramain Mart, Grosir Haramain, Haramain Trans, Haramain Pro Chicken, Haramain Restaurant,Haramain Water, Haramain Laundry, Kantin Haramain,Gas Haramain,Rumah Jamur Haramain, Lele Haramain,Bakso Haramain (Bahrain), Mini Bank, dan Lele Haramain.

Hal ini sebagaimana keterangan yang disampaikan oleh penanggung jawab bagian usaha di pondok pesantren nurul haromain:

"Alhamdulillah, mulai sejak berdirinya Pondok Pesantren Nurul Haromain hingga saat ini, unit usaha yang suadah dijalankan berjumlah empat belas unit yaitu, Haramain Mart, Grosir Haramain, Haramain Trans, Haramain Pro Chicken, Haramain Restaurant, Haramain Water, Haramain Laundry, Kantin Haramain, Gas Haramain, Rumah Jamur Haramain, Lele Haramain, Bakso Haramain (Bahrain), Mini Bank, dan Lele Haramain." 40

Hal senada juga disampaikan oleh manajer usaha Pondok Pesantren Nurul Haromain:

"Benar sekali, dari sejak didirikannya Pondok Pesantren ini hingga sekarang sudah ada 14 belas unit usaha yang dibuk". ${ }^{41}$

Tujuan utama dibentuknya unit-unit usaha pondok pesantren tersebut adalah untuk memenuhi kebutuhan santri. Sebagai contoh, Enha Trans dibentuk untuk membantu terealisasinya program kerja santri berupa touring ke luar daerah sekali dalam setahun dan study tour ke beberapa pondok pesantren di Lombok secara bertahap dan bergantian.

${ }^{39}$ Iskandar, Metode Penelitian Pendidikan dan sosial, (Jakarta: GP Press, 2008), 228

40Sunarto, Wawancara, Narmada, 2 Juni 2019.

41Anwar Thayyib, Wawanca, Narmada, 2 Juni 2019. 
Kemudian Haramain Water yang menyediakan air galonan yang menyiapkan dua galon air didepan kamar santri setiap harinya sehingga mereka tidak perlu menyimpan air didalam kamar atau lemari mereka masing-masing. Haramain Laundry juga dibentuk untuk menghindari kehilangan baju yang sering disebabkan oleh karena santri terkadang lupa mengangkat jemuran mereka. ${ }^{42}$

Menurut Ahmad Dahlan terpenuhinya kebutuhan santri secara menyeluruh dapat meminimalisir interaksi santri dengan masyarakat luar. Ini juga merupakan poin penting bagi santri karena ketika santri terlalu banyak melakukan interaksi dengan orang luar dapat menimbulkan kehawatiran santri akan terpengaruh oleh pola hidup mereka, baik dari segi penampilan, cara bersikap dan berbicara, dll. Dengan begitu dapat disimpulkan bahwa secara tidak langsung unit usaha tersebut memiliki peran penting dalam perkembangan psikologis santri yang juga berpengaruh pada perkembangan sistem pendidikan pondok pesantren.

Berdasarkan hasil observasi tampak bahwa untuk tercapainya tujuan-tujuan tersebut, dengan merujuk pada visi dan misi pondok pesantren Nurul Haramain, kordinator usaha berupaya menyusun struktur manajemen usaha sebaik mungkin. Sebelum memulai suatu kegiatan ataupun tindakan terkait hal apapun di pondok pesantren Nurul Haramain, pengurus harus melakukan perencanaan yang baik dan matang sehingga mampu memberikan hasil yang maksimal, begitupun dengan kegiatan kewirausahaan. ${ }^{43}$

Sehubungan dengan perencanaan ini peneliti sempat meminta jawaban dari manajer usaha Pondok Pesantren Nurul Haromain:

"Hal ini selalu dilakukan kordinator usaha pondok pesantren Nurul Haramain sebelum membentuk ataupun menjalankan satu unit usaha sehingga mampu memberi manfaat secara maksimal. Manfaat yang dimaksudkan tidak hanya dalam bentuk profit atau keuntungan, tetapi lebih kepada manfaat pendidikan dan pengalaman berwirausaha bagi para pengelola". ${ }^{4}$

Jawaban dari manajer usaha itu sejalan dengan pendapatnya Naja Hasanuddin tentang perencanaan. Perencanaan (planning) merupakan proses pemilihan informasi dan pembuatan asumsi mengenai keadaan dimasa yang akan datang untuk merumuskan kegiatan-kegiatan yang perlu dilakukan dalam rangka pencapaian tujuan yang telah ditetapkan

${ }^{42}$ Sunarto, Wawancara, Narmada, 2 Juni 2019.

43 Peneliitian di ponpes Nurul Haramain pada 1 Juni 2019.

${ }^{44}$ Anwar Thayib, Wawancara, Narmada, 02 Juni 2019.

298 JURNAL LISAN AL-HAL 
sebelumnya. ${ }^{45}$ Hal-hal yang difokuskan dalam perencanaan usaha adalah penentuan pengelola (stake holder) yang tepat pada waktu yang tepat pula. Meskipun salah satu tujuan berdirinya unit usaha adalah sebagai media pendidikan bagi para alumni, tetapi kordinator usaha juga tidak sembarangan menunjuk orang sebagai penanggung jawab maupun pengelola satu unit usaha pondok, begitupun waktunya. Alumni yang masa pengabdiannya lebih lama lebih diutamakan karena pastinya mereka akan lebih siap menerima tanggungjawab baik dari segi mental maupun potensi dibandingkan dengan pengabdi junior. 46

Selain itu, perencanaan keseluruhan unit usaha pesantren Nurul Haramain tidak merata, sebagian usaha direncanakan dengan matang sehingga membutuhkan waktu agak lama sebelum eksekusi, dan ada juga usaha yang terbentuk dadakan. Mendadak disini bukan berarti tanpa persiapan sama sekali, melainkan pelaksanaan yang terbilang cepat meskipun tenaga, sarana dan bahan yang dibutuhkan belum tersedia maksimal. ${ }^{47}$

Beberapa unit usaha yang memerlukan perencanaan dan persiapan cukup lama yaitu Haramain Pro Chicken, Haramain Mart, Haramain Grosir, Haramain Jaya Bangunan, Haramain Water, Haramain Trans, Gas, Rumah Jamur Haramain dan Lele. Hal ini dikarenakan beberapa alasan seperti pengurusan izinpemilihan dan persiapan tempat, penyediaan alat dan bahan-bahan, persiapan tenaga ahli dan rancangan pembagian hasil karena sebagiannya melibatkan guru-guru dan juga masyarakat dalam pengumpulan modal. 48

Sebaliknya, usaha kantin Haramain, Haramain Resto, Bakso Haramain (Bahrain) dan Haramain Laundry terlaksana dengan cepat. Beda halnya dengan Haramain Mart ataupun Grosir Haramain yang menyediakan peralatan kebutuhan santri seperti alat tulis (ATK), peralatan mandi, dan makanan ringan yang mana produk-produk tersebut disiapkan sendiri dari pihak pengelola, kantin dan resto Haramain justru hanya menyediakan makanan siap saji seperti nasi, gorengan, lauk pauk, dan aneka minuman yang merupakan produk titipan beberapa guru dan juga masyarakat setempat. Sistem titipan ini juga mengurangi resiko kerugian pengelola karena jika produk titipan tidak habis terjual maka sisanya dikembalikan pada penitip. Dari fakta ini dapat disimpulkan

45 Naja Hasanuddin Rahman Daeng, Manajemen Fit and Profer Test. (Yogyakarta: Pustaka Widyatama, 2004), 23.

46 Penelitian di ponpes Nurul Haramain pada 1 Juni 2019

${ }^{47}$ Sunarto, Wawancara,Narmada, 2 Juni 2019.

48 Juwaini, Wawancara, Narmada, 3 Juni 2019. 
bahwa keterbatasan produk yang disediakan serta model penerimaan titipanlah yang memudahkan terbentuknya usaha ini. ${ }^{49}$

\section{Dinamika Usaha Pondok Pesantren Nurul Haramain}

Menurut Puji Hartono, pelaksanaan pengelolaan usaha pondok pesantren Nurul Haramain melibatkan para guru dan juga alumni pengabdi. Ada beberapa alasan mengapa penanggungjawab usaha Nurul Haramain lebih memilih para guru dan alumni sebagai pengelola usaha pondok (stake holder) dibandingkan orang lain yaitu: untuk menumbuhkan jiwa dan memberikan ilmu kewirausahaan, memperhatikan kesejahteraan hidup guru, sebuah upaya simbiosis mutualisme dengan pondok pesantren, dan kepercayaan yang tinggi terhadap guru dan alumni dibanding orang lain. ${ }^{50}$

Poin terpenting adalah tingkat kepercayaan karena dilibatkannya mereka dalam pengelolaan usaha pondok merupakan sebuah tugas dan tanggungjawab, bukan sebuah pekerjaan ataupun mata pencaharian. Menurut Hutbi, mindset ini sangat berpengaruh terhadap proses pengelolaan usaha. Ketika melihat keterlibatannya sebagai tugas dari pondok dan harus dipertanggungjawabkan maka yang mereka fikirkan adalah upaya-upaya untuk menjalankan tugas tersebut dengan baik dan maksimal sehingga mampu mendatangkan keberkahan untuk kehidupan mereka. Sedangkan jika hal ini dipandang sebagai sebuah pekerjaan, maka yang muncul dari fikiran mereka justru apa dan berapa yang akan saya peroleh yang mencerminkan ketidakikhlasan. Dengan begitu, jika ternyata harapan mereka tidak sesuai, bisa saja mempengaruhi kinerja dan tidak tertutup kemungkinan mereka akan meninggalkan usaha tersebut begitu saja. ${ }^{51}$

Selain melibatkan para guru dan alumni, pihak pondok juga menilai perlunya kerjasama atau bermitra dengan pihak luar untuk memperluas jaringan. Selama ini sudah terbentuk beberapa bentuk kerjasama, yaitu:

a) Kerjasama dengan PT. Dawipa pada tahun 2014 untuk memulai usaha tabung gas. Model kerjasama yang disepakati adalah investasi dengan keuntungan $2 \%$ dari total investasi perbulannya.

b) Kerjasama dengan Bank Indonesia pada tahun 2017 untuk pengadaan rumah jamur Haramain. Pihak Bank Indonesia menyerahkan dana hibah senila Rp. 100.000.000 karena pondok pesantren Nurul Haramain

49 Juwaini, Wawancara, Narmada, 3 Juni 2019.

50 Sunarto, Wawancara, Narmada, 2 Juni 2019.

51 Anawar Thayyib, Wawancara, Narmada, 03 Juni 2019.

$300 \mid$ JURNAL LISAN AL-HAL 
dinilai sebagai lembaga pendidikan berbasis wirausaha yang berhak dan mampu mengelola usaha tersebut.

c) Kerjasama dengan Dinas Kelautan pada tahun 2017 untuk usaha lele berbasis bioflok. Pondok pesantren Nurul Haramain menerima dana sebesar Rp. 200.000.000 dari Dinas Kelautan yang dimanfaatkan untuk pembuatan 10 bioflok yang kemudian masing-masing bioflok diisi dengan 3000 ikan lele.

d) Kerjasama dengan owner outlet Pro Chicken pada tahun 2015 untuk usaha ayam goreng.

e) Kerjasama dengan masyarakat dan para guru yang lebih dikenal dengan sebutan konsep jama'ah untuk berbagai jenis usaha seperti laundry, tabung gas, jamur, dan lele. ${ }^{52}$

Berbeda halnya dengan kebanyakan pondok pesantren yang mendirikan unit usaha dan kemudian diklaim sebagai milik pribadi pimpinan atau keluarga pimpinan pondok, di pondok pesantren Nurul Haramain justru tidak ditemukan istilah usaha milik pribadi. Keseluruhan usaha merupakan milik pondok sehingga keseluruhan hasil atau keuntungannya diserahkan untuk pondok setelah dikurangi persenan untuk pengelola dan penanggungjawab unit usaha. Dengan begitu tidak akan ada rasa memiliki dan kecemburuan sosial antara satu dengan yang lain. ${ }^{53}$

Kebijakan kordinator usaha untuk meniadakan usaha milik pribadi tentunya mampu memberikan dampak positif terhadap tanggapan masyarakat dan guru-guru tentang manajemen usaha pondok pesantren Nurul Haramain. Tetapi dari sisi lain ini berarti tidak memungkinkan menerima dana sebagai modal dari orang atau instansi tertentu.

Oleh karena itu dibentuklah beberapa jenis program untuk pengumpulan dana sebagai modal berupa:

1. Konsep jama'ah : merupakan hal yang lumrah di pondok pesantren Nurul Haramain, demikian pula untuk memulai sebuah usaha. Setiap guru mengeluarkan sejumlah uang sesuai kesepakatan dan kemudian nantinya akan mendapatkan persenan atau bagi hasil setelah usaha yang diniatkan berjalan.

2. Potongan ihsan (honor guru) Selain melalui konsep jama'ah, modal juga terkumpul melalui potongan honor guru perbulannya senila Rp. 10.000. Berbeda dengan konsep jama'ah yang memang hanya diikuti oleh sebagian guru dan bahkan melibatkan masyarakat luar, pemotongan

52 Sunarto, Wawancara, Narmada, 2 Juni 2019.

53 Penelitian di ponpes Nurul Haramain pada 1 Juni 2019 
honor ini meliputi keseluruhan guru pengajar di pondok pesantren Nurul Haramain.

3. Mini Bank : merupakan salah satu program pondok pesantren Nurul Haramain yang mana selain untuk melatih santri berhemat dan bertanggungjawab atas keuangan mereka juga bertujuan untuk menghindari kehilangan uang. Jadi santri dihimbau untuk menyimpan uang mereka di Mini Bank ini dan bisa diambil setiap ada keperluan. Uang yang tersimpan inilah yang kemudian dimanfaatkan sebagai modal usaha. Metode ini dapat memudahkan pondok pesantren mendapatkan dana cash untuk memulai suatu usaha sehingga tidak perlu peminjaman modal ke bank. ${ }^{54}$

Dalam proses pemasaran, khususnya untuk usaha yang bergerak dibidang makanan seperti Enha Mart, Kantin, Pro Chicken dan Haramain Restaurant tidaklah sama dengan pemasaran di luar yang open sepanjang hari. Pengelola harus memperhatikan jam belajar, kegiatan siswa dan kegiatan kumpul guru untuk disesuaikan dengan waktu beroperasi. Akan menjadi sebuah bahan evaluasi jika pengelola beroperasi pada jam aktif kegiatan dan belajar santri karena dikhawatirkan mengganggu. Pengelola, sebagai seorang pendidik juga lebih diarahkan mengikuti kumpul atau rapat guru pada waktunya daripada izin untuk beroperasi. ${ }^{55}$

Secara keseluruhan, Sunarto menilai hal tersebut bukanlah sebuah kendala bagi pengelola unit usaha tersebut. Justru yang tercatat sebagai kendala pelaksanaan usaha-usaha tersebut adalah masih ada sejumlah santri yang belanja di luar pondok, pengelola tidak dapat menyesuaikan waktu beroperasi dengan jadwal perkuliahan, banyaknya jam mengajar pengelola sehingga fokus mengurus usaha berkurang. ${ }^{56}$

Tetapi bagaimanapun, dengan kendala-kendala yang ada proses pelaksanaan usaha pondok selama ini dinilai sudah berjalan maksimal. Kesimpulan ini didukung dengan bukti-bukti diantaranya semua unit usaha masih tetap berjalan hingga saat ini, mampu memberikan sumbangsih terhadap kegiatan santri dan pembangunan pondok pesantren, serta jarang terdengar komplain dari konsumen. Sunarto menilai justru proses inilah yang penting dan bukan keuntungan (profit) yang dihasilkan. ${ }^{57}$

Terkait hasil atau profit yang diperoleh, setiap bulannya akan

54 Sunarto, Wawancara, Narmada, 2 Juni 2019.

55 Sunarto, Wawancara, Narmada, 3 Juni 2019.

56 Sunarto, Wawancara, Narmada, 03 Juni 2019.

57 Sunarto, Wawancara, Narmada, 03 Juni 2019.

302 JURNAL LISAN AL-HAL 
diadakan pengecekan oleh masing-masing stake holder usaha dan pembagian hasil yang diketuai oleh kordinator usaha. Menggunakan teknik prosentase, hasilnya kemudian dialokasikan untukninfaq 2,5\%, tabungan $10 \%$,pengelola $25 \%$, dan sisanya untuk kebutuhan pondok. ${ }^{58}$

Menurut Puji Hartono selaku pengelola usaha, ada beberapa poin penting yang patut dicontoh dari pelaksanaan usaha pondok pesantren Nurul Haramain. Poin-poin tersebut adalah konsep jama'ah, tidak ada usaha milik pribadi, penanaman pola fikir bahwa usaha merupakan ladang perjuangan dan pengabdian, bukan ladang penghidupan, mengutamakan kepercayaan pada guru dan alumni pengabdi pondok, kepekaan terhadap kebutuhan santri dan kesejahteraan guru, danyang utama adalah proses, bukan hasil. 59

Sebagaimana biasanya setiap hendak menjalankan suatu usaha, yang paling utama terfikirkan pasti adalah keuntangan ataupun manfaat dari usaha yang dijalankan. Hal serupapun terjadi pada Pondok Pesantren Nurul Haromain yang ketika masa awal pembukaan unit usaha. Keadaan semacam ini peniliti tau dari tanggapan Bapak KABID usaha Pondok Pesantren Nurul Haromain. Tanggapan lengkapnya sebagai berikut:

"Dulu pada masa-masa awal berdirinya Pondok Pesantren ini kan tidak punya penghasilan sendiri atau dengan bahasa lain masih belum punya usaha sendiri. Berangkat dari sana semuanya berfikiran bagaimana agar supaya Pondok Pesantren memiliki penghasilan sendiri, akan tetapi tidak bisa langsung menjalankan usaha, karena ada beberapa pertimbangan yang membuat kami semua masih belum bisa membuka usaha, diantara pertimbangannya adalah: ketika hendak membuka usaha, keuntungan atau manfaat apa yang bisa diberikan baik kepada Pondok Pesantren, Santri ataupun Masyarakat."60

Seiring dengan bertambahnya kepercayaan masyarakat untuk memondokkan putra-putrinya di Pondok Pesantren Nurul haromain secara otomatis kebutuhan para Santri semakin beragam, oleh karananya manafaat yang ditebarkan oleh unit usaha yang ada harus bias mengimbangi kebutuhan para Santri. Hal senada Peneliti peroleh dari wawancara dengan penanggung jawab usaha PONPES Nurul Haromain:

"Dengan kuantitas Santri yang setiap tahunnya bertambah, kami sebagai penanggung jawab bidang usaha harus seintens mungkin

58 Juwaini, Wawancara Narmada, 3 Juni 2019.

59 Sunarto, Wawancara, Narmada, 03 Juni 2019.

60 Juwaini, Wawancara, Narmada, 03 Juni 2019. 
dalam memikir dan mewujudkan kemandirian ekonomi Pesantren. Dengan demikian Pesantren dapat mengimbangi kebutuhan para Santri". 61

Tidak hanya kepada para Santri, manfaat dari unit usaha yang adapun direncanakan bisa berinflikasi ke masyarakat setempat pada khususnya dan masyarakat luar pada umumnya, maka dari itu dibukalah salah satu unit usaha yang bernama NH MART dan TRANS NH.

"secara mikro benar sekali bahwa unit usaha ini diperuntukkan kepada para Santri namun secara makro tidak demikian, unit usahapun diperuntukan kepada para masyarakat. Buktinya dengan dibukanya NH MART dan TRANS NH, itu suadah membuktikan bahwa unit usaha yang ada sudah dapat dirasakan manfaatnya oleh siapa saja, baik yang Santri maupun yang bukan Santri. NH MART menyediakan segala macam kebutuhan pangan dan TRANS NH bagi siapa saja yang berkeinginan touring karena disana sudah disiapkan tiga Mobil Bis. Sambung bapak Manajer". 62

Setiap usaha harus melakukan etika bisnis yang mana dengan etika bisnis konsumen akan tertarik untuk menkonsumsi ataupun menikmati produk-produk yang di sediakan oleh unit usaha yang ada pada Pondok Pesantren Nurul Haromain itu sendiri. Etika bisnis yang diterapkan oleh setiap unit usah yang ada di Pondok Pesantren Nurul Haromain Narmada Lombok Barat adalah dengan penerapan kejujuran, keramahan, kerapian dan kesopanan sebagaimana yang di paparkan oleh Bapak Juwaini selaku KABID usaha Pondok Pesantren Nurul Haromain Naramada Lombok Barat:

"Untuk pelayanan kepada para konsumen, kami menerapkan sistem kejujuran, keramahan, kerapian dan kesopanan. Dimana sistem jujur dalam harga barang dan laba bagi Pondok Pesantren kami. Sistem ramah kami dalam melayani para konsumen yang akan membeli maupun sistem ramah kami dalam melayani masyarakat yang hendak menanyakan modal awal jika ingin memebuka usaha yang sama. Sistem kerapian yang kami maksud adalah seragam yang ala santri, karena usaha yang kami jalankan ini berada dibawah naungan Pondok Pesantren dan para kariyawannya pun para alumni dari Pondok pesantren itu sendiri. Dan untuk sistem kesopanan, kami menerapkan kepada seluruh yang ada distruktur usaha, mulai dari kariyawan sampai kepada KABID harus mengucapkan salam terlebih dahulu

${ }^{61}$ Sunarto, Wawancara, Narmada 03 Juni 2019.

${ }^{62}$ Anwar Thayyib, Wawancara, Narmada, 03 Juni 2019.

304 JURNAL LISAN AL-HAL 
kepada para konsumen". 63

Dan dilanjutkan oleh Bapak Sunarto selaku penanggung jawab usaha Pondok Pesantren Nurul Haromain:

"Untuk pelayanan bagi masyarakat dan para santri (konsumen) kami, kami menerapkan sistem ramah kepada sesama dan menerapkan 3S (Senyum, Sapa dan Salam). Karena etika merupakan suatu hal yang paling utama dalam berbisnis atau berwirausaha."64

Sifat jujur atau dapat dipercaya kepada seseorang merupakan sifat terpuji yang disenangi Allah. Jujur tidak hanya diartikan secara harfiyah sebagai berkata benar, mengakui atau memberikan suatu informasi yang sesuai dengan kenyataan dan kebenaran. Melainkan dalam pengertian luas, tidak berbohaong tidak menipu, tidak mencuri, tidak korupsi, tidak berbuat curang, tidak selingkuh, merupakan bentuk lain dari kejujuran.

"Jujur yang menjadi tendensi disini adalah jujur secara yuniversal, para karyawan atau siapa saja yang berada dibawah naungan usaha Pondok Pesantren Nurul Haromain, mereka semua tidak hanya ditekankan untuk jujur kepada para konsumen, bahkan kepada siapa saja mereka berinteraksi meraka diharuskan agar selalu menjunjung tinggi nilai-nilai kejujuran, jika tidak di indahkan maka akan berkonsekuensi pada karier mereka". Ungkap bapak Anwar diselasela menikmati jamuan yag sudah dihidangkan. ${ }^{65}$

Dengan demikian unit usaha yang berada dibawah naungan Pondok Pesantren Nurul Haromain Narmada Lombok Barat sudah menerapkan sistem etika bisnis atau berwirausaha Islam dengan menerapkan sistem kejujuran, keramahan, kerapian dan kesopanan bagi masyarakat dan santri yang akan menggunakan jasa dan prduknya (konsumen).

\section{J. Faktor Pendukung Dan Penghambat Manajemen Usaha dan Kemandirian Ekonomi Di Pondok Pesantren Nurul Haromain}

Kegiatan proses manajemen usaha perlu adanya faktor pendukung demi terlaksananya kemandirian ekonomi Pondok Pesantren dengan waktu yang relative cepat. Berikut wawancara dengan Bapak Juwaini selaku KABID usaha yang ada di Pondok Pesantren Nurul Haromain:

"Faktor yang mendukung berjalannya manajemen usaha yang ada di unit usaha Pondok Pesantren Nurul Haromain hingga saat adalah kesediaan Alumni, Wali Santri dan Simpatisan Pondok Pesantren

63 Juwaini, Wawancara, Narmada, 3 Juni 2019.

64 Sunarto, Wawancara, Narmada, 3 Juni 2019.

65 Anwar Thayyib, Wawancara, Narmada, 3 Juni 2019. 
Nurul Haromain yang sudah menjalankan usaha yang sama dengan usaha yang ada di Pondok Pesantren Nurul Haromain menyalurkan tenaga dan fikirannya dalam mengelola unit usaha yang ada di Pondok Pesantren Nurul Haromain".66

Jadi setelah peneliti terjun ke lapangan maka dapat disimpulkan bahwa yang menjadi faktor pendukung bagi unit usaha yang ada di Pondok Pesantren Nurul Haromain dalam menjalankan manajemen usahanya tersebut adalah kesediaan Alumni, Walai Santri dan Simpatisan untuk membantu para kariyawan untuk menjalankan manajemen pada saat dibutuhkan. Di setiap menjalankan suatu usaha tidak selamanya akan selalu berjalan baik meskipun memiliki manajemen yang bagus maka tetap pula akan selalau ada faktor pendukung dan fakor penghambat.

Menurut Bapak Juwaini selaku KABID usaha yang ada di Pondok Pesantren Nurul Haromain mengatakan bahwa:

"Salah satu faktor yang menjadi penghambat selama ini ialah minimnya kariyawan yang kompeten dibidangnya, dan keberadaan beberapa unit didalam komplek Pesantren". ${ }^{67}$

Setelah peneliti melakukan penelitian denga wawancara maka peneliti dapat menyimpulkan bahwa disetiap usaha yang dilakukan oleh seseorang pastilah mengalami suatu kegagalan atau masalah yang akan dihadapi tetapi juga ada jalan keluarnya. Ada sesuatu yang mendukung usaha mereka dan juga ada yang menjadi penghambat bagi usahanya. Begitu pula dengan unit usaha yang ada di Pondok Pesantren Nurul Haromain juga mengalami hal tesebut tentu unit usaha yang ada di Pondok Pesantren Nurul Haromain sebelum melakukan usaha tersebut pasti sudah memikirkan sesuatu yang akan terjadi di depannya, sehingga unit usaha yang ada di Pondok Pesantren Nurul Haromain dalam merintis usahanya tersebut selalu dipasrahkan kepada sang pencipta dan selalu mengutamakan kemakmuran para santri serta masyarakat sekitar.

\section{K. Simpulan}

Berdasarkan paparan data dan pembahasan tentang manajemen unit usaha di Pondok Pesantren Nurul Haramain di atas, ada beberapa poin yang dapat disimpulkan: Pertama, Pondok Pesantren Nurul Haramain memiliki 14 jenis usaha yang bergerak di bidang yang berbeda. Proses manajemen keseluruhan unit usaha tersebut meliputi rancangan usaha, dinamika usaha Pondok Pesantren, manfaat usaha dan etika berwirausaha

66 Juwaini, Wawancara,Narrmada, 2 Juni 2019.

67 Juwaini, Wawancara, Narmada, 2 Juni 2019.

306 JURNAL LISAN AL-HAL 
dalam Islam. Model manajemen yang di aplikasikan di unit usaha yang ada di Pondok Pesantren Nurul Haromain adalah model Planning, Organizing, Actuiting dan Controlling yang pada akhirnya disingkat dengan model POAC.

Kedua, Faktor Pendukung: Kesediaan alumni, wali santri dan simpatisan untuk membantu baik secara tenaga dan fikiran pada saat dibutuhkah, banyaknya kepercayaan dan minat konsumen, pelayanan yang cukup baik serta harga yang di patok relatif murah. Sedangkan faktor penghambatnya yaitu: Minimnya karyawan yang mempuni dibidangnya dan keberadaan beberepa unit usaha didalam komplek Pesantren, akibatnya usaha tidak dapat berjalan dengan semestinya.

\section{DAFTAR PUSTAKA}

Ahmad, Mushtaq, Etikabisnis dalam Islam, Jakarta Timur: Pustaka AlKautsar. 2010.

Antonio, Muhammad Syafii, Muhammad SAW The Super Leader, Super Manager, Netlibrary E-Book.

Anwar, Sekolah Madrasah Berkualitas", dalam http://portalgaruda.org/article.php05. 2019.

Hadi, Sustrisno, Metodologi Research, Yogyakarta: Andi Offset. 1981.

Halim, A., et al. tt, Manajemen Pesantren, Yogyakarta: Pustaka Pesantren

Halim, Abdullah, et al.tt, Manajemen Pesantren, Yogyakarta: Pustaka Pesantren

Hamid, Abdullah, Pendidikan Karakter Berbasis Pesantren, Surabaya: Imtiyaz. 2017.

Hasanuddin Rahman Daeng, Naja, Manajemen Fit and Profer Test, Yogyakarta: Pustaka Widyatama. 2004.

Iskandar, Metode Penelitian Pendidikan dan sosial, Jakarta: GP Press. 2008.

Isma'il, Muhammad bin, Sarah Shohih Bukhari, Damaskus: Dar Al-Bayan, 1990.

Kementrian Agama RI, Al-Quran dan Terjemah, Bandung: CV Diponogoro. 2010.

Ma'shum, Saifullah, Fiqih Islam Lengkap. Pedoman Hukum Ibadah Umat Islam dengan Berbagai Permasalahannya, Surabaya: Terbit Terang. 2000.

Muhadjir, Noeng, Metodologi Penelitian Kualitatif, Yogyakarta: PT Bayu Indah Grafik. 1996.

Muhammad, Metodelogi Penelitian Ekonomi Islam, Jakarta: Rajawali Pers. \begin{tabular}{l|l} 
JURNAL LISAN AL-HAL & 307
\end{tabular} 
2008.

Nashruddin Baidan and Erwati Aziz, Etika Islam dalam Berbisnis, Jawa Tengah: Zada Haniva. 2008.

Oktavia, Lenny, et al. Pendidikan Karakter Berbasis Tradisi Pesantren, Jakarta: Tim Penulis Rumah Kitab. 2014.

Purnawanto, Budy, Manajemen SDM Berbasis Proses, Yogyakarta: Pustaka Widyatama. 2004.

Rofiq A. et al., Pemberdayaan Pesantren Menuju Kemandirian dan Profesionalisme Santri dengan Metode Daurah Kebudayaan, Yogyakarta: Pustaka Pesantren. 2005.

Sugiono, Metode Penelitian Kuantitatif, Kualitatif dan R\&D, Bandung: PT Remaja. 2012.

Sulthon \& Khusnuridlo, Manajemen Pondok Pesantren dalam Perspektif Global. Yogyakarta: LaksBang PRESSindo. 2016.

Surahmad, Winarno, Pengantar Penelitian Ilmiah dan Metode Tehnik, Bandung: Alfabeta. 1990.

Tanjung, A. Budaya Bisnis Menuju Kebangkitan Ekonomi Syariat, Jakarta: Dewan Pimpinan Majelis Ulama Indonesia, 2012.

W. Griffin, Ricky, Manajemen, Jakarta: Erlangga. 2004.

W. Zimmerer, Thomas, et al. Essentials of Enterpreneurship and Small BusinesManagement. Kewirausahaan dan Manajemen Usaha Kecil, Jakarta: Salemba Empat. 2008.

Wijayanto, Dian, Pengantar Manajemen, Jakarta: PT Gramedia Pustaka Utama. 2012.

Wijayanto, Dian, Pengantar Manajemen, Jakarta: PT Gramedia Pustaka Utama. 2012.

Zainudin, A. Ketika Sukses Berawal dari Pesantren. Bekasi: MJWBook PT EMJEWE, 2014.

308 JURNAL LISAN AL-HAL 